\title{
Protocol
}

\section{Polyethylene Glycol Fusion for Hybridoma Production}

\author{
Edward A. Greenfield
}

Once a good immune response has developed in an animal and an appropriate screening procedure has been developed, the construction of hybridomas is ready to begin. Polyethylene glycol (PEG) is the fusing agent of choice for hybridoma production, allowing the rapid and manageable fusion of mammalian cells. PEG fuses the plasma membranes of adjacent myeloma and/or antibody-secreting cells, forming a single cell with two or more nuclei. This heterokaryon retains these nuclei until the nuclear membranes dissolve before mitosis. In this protocol, antibody-secreting cells are isolated from the appropriate lymphoid tissue (mouse spleen and lymph nodes), mixed with myeloma cells, centrifuged to generate good cell-to-cell contacts, and fused with PEG. The fused cells are then diluted into selective medium and plated in multiwell tissue culture dishes. Beginning $\sim 1$ wk later, samples of the tissue culture supernatants are removed from wells that contain growing hybridomas and tested for the presence of the appropriate antibodies. Cells from positive wells are grown, single-cell-cloned, and frozen. A procedure for screening batches of PEG for efficacy before hybridoma fusion is also included.

\section{MATERIALS}

It is essential that you consult the appropriate Material Safety Data Sheets and your institution's Environmental Health and Safety Office for proper handling of equipment and hazardous materials used in this protocol.

RECIPES: Please see the end of this protocol for recipes indicated by $<R>$. Additional recipes can be found online at http://cshprotocols.cshlp.org/site/recipes.

Reagents

Culture medium (with and without 10\% fetal bovine serum [FBS]) (for screening PEG samples)

D-10 medium for hybridomas $<\mathrm{R}>$

DMEM

HAT fusion medium $<\mathrm{R}>$

HT medium (HAT medium without aminopterin)

Mouse spleen or lymph nodes, fresh (see Step 14)

Harvest tissues according to Protocol: Harvesting Tissue from Immunized Mice, Rats, and Hamsters (Greenfield 2017).

MRC-5 cells

Myeloma cells (for screening PEG samples)

PBS (50 mL/fusion)

Polyethylene glycol (PEG) 1450, including samples for screening if needed

Fusions require very little PEG, and thus good batches of this reagent will last a long time. Bad batches contain trace amounts of toxic chemicals. For PEG screening, see Steps 1-7. However, only the occasional batch of PEG is

From the Antibodies collection, edited by Edward A. Greenfield.

(C) 2018 Cold Spring Harbor Laboratory Press

Cite this protocol as Cold Spring Harb Protoc; doi:10.1101/pdb.prot103176 
E.A. Greenfield

unusable, and differences in batches are normally small. Most researchers do not bother to test different lots of PEG, but, as a precaution, buy the highest grade of PEG that is available. The American Type Culture Collection (ATCC), Invitrogen, and Roche supply high-quality PEG that does not need to be tested before use.

SP $2 / 0$ cells

Trypan Blue

Equipment

Cell strainer $(70 \mu \mathrm{m})$

Centrifuge tubes (50 and $15 \mathrm{~mL}$ )

$\mathrm{CO}_{2}$ incubator

Countess Cell Counter or hemocytometer

Falcon tubes

Multichannel pipette

Petri dishes or culture dishes

Syringe piston

T25 flasks

Tissue culture dishes (96-well) (flat-bottomed)

Vacuum manifold

Water bath at $50^{\circ} \mathrm{C}$ (for screening PEG samples)

Water baths at $60^{\circ} \mathrm{C}$ and $37^{\circ} \mathrm{C}$

\section{METHOD}

Most PEG fusion techniques are based on the work of Galfre et al. (1977).

\section{Screening for Good Batches of PEG}

1. Add $100 \mu \mathrm{L}$ of medium containing $10 \%$ serum to each well of a 96 -well tissue culture dish (one dish per batch of PEG to be tested).

2. Wash myeloma cells by centrifuging at $400 \mathrm{~g}$ for $5 \mathrm{~min}$ (use $\sim 10^{6}$ cells per assay). Resuspend the cells in medium without serum and centrifuge again.

3. While washing the myeloma cells, melt one vial $(0.5 \mathrm{~g})$ of each of the PEG samples to be tested in a water bath set at $50^{\circ} \mathrm{C}$. Add $0.5 \mathrm{~mL}$ of medium without serum to each vial, and place it in a water bath set at $37^{\circ} \mathrm{C}$.

4. Resuspend the cells in medium without serum, and aliquot samples containing $10^{6}$ cells into fresh centrifuge tubes (one tube per batch of PEG). Centrifuge at $800 \mathrm{~g}$ for $5 \mathrm{~min}$. Carefully remove the supernatant from the cell pellet.

5. Resuspend each cell pellet with a different batch of PEG solution by pipetting up and down. Include one control that is resuspended in medium without serum or PEG. Incubate for $2 \mathrm{~min}$ at room temperature. Add $10 \mathrm{~mL}$ of medium containing $10 \%$ FBS. Take $100 \mu \mathrm{L}$ of this suspension, and dilute it into a second $10 \mathrm{~mL}$ of medium containing $10 \%$ FBS. Centrifuge the final dilution at $400 \mathrm{~g}$ for $5 \mathrm{~min}$.

6. Aspirate the supernatant, and resuspend the myeloma cells in $1 \mathrm{~mL}$ of medium with serum. Transfer $100 \mu \mathrm{L}$ of the cell suspension into each of the eight wells on the left-hand side of the 96-well tissue culture dish. Using an eight-well multichannel pipette, perform serial 1-in-2 dilutions across the plate. Return to the $\mathrm{CO}_{2}$ incubator.

7. Check the plates after $14 \mathrm{~d}$. Good batches of PEG will only slightly inhibit growth and will resemble the "no PEG" controls. Other batches should be discarded. 
The Day before Fusion

Use D-10 medium for both the MRC-5 and SP 2/0 cultures.

8. Make sure that there are enough SP 2/0 cells. Split them at 1:1 so that they will be in log phase at the time of fusion.

9. Plate MRC-5 cells in flat-bottomed 96-well plates, $100 \mu \mathrm{L} /$ well (one frozen vial of MRC-5 cells is good for eight plates).

10. Wash the MRC-5 cells in D-10 medium once at $1200 \mathrm{rpm}$ for $5 \mathrm{~min}$ and then plate.

\section{Sample Preparation}

11. Thaw the PEG 1450 by incubating it for $5-10 \mathrm{~min}$ at $\sim 60^{\circ} \mathrm{C}$. Once thawed, add $2 \mathrm{~mL}$ of PBS, and leave the vial at $37^{\circ} \mathrm{C}$ until further use. Take $50 \mathrm{~mL}$ of PBS in a Falcon tube, and leave it in the $37^{\circ} \mathrm{C}$ water bath. Warm the Dulbecco's modified Eagle's medium (DMEM) and other medium ingredients to room temperature.

12. Collect the SP 2/0 cells (split 1:1 the previous day to keep the cells in log phase). Wash once in DMEM (with no additives such as serum or antibiotics) at $1200 \mathrm{rpm}$ for $5 \mathrm{~min}$ at room temperature.

For a typical 10-plate fusion, at least 15 T7 5 flasks of SP 2/0 cells are required. They need to be split 1:1 the previous day to keep the cells in log phase.

13. Resuspend the cells in 25-50 mL of DMEM. Keep the cells on ice until further use.

14. Aseptically remove the spleen and/or lymph nodes from the freshly killed mouse. Place the tissues in DMEM with no additives in a 50-mL tube until further use.

15. Place the spleen in a Petri dish containing $\sim 5 \mathrm{~mL}$ of DMEM. Mash it using the back of the syringe piston. Make sure that the entire spleen is thoroughly mashed.

16. Collect spleen cells from the Petri dish, and pass them through a $70-\mu \mathrm{m}$ strainer into a $50-\mathrm{mL}$ conical tube.

Skip Steps 14 and 15 if using frozen splenocytes.

17. Wash the cells in DMEM once at $1400 \mathrm{rpm}$ for $7 \mathrm{~min}$, resuspend them in 10-25 $\mathrm{mL}$ of DMEM, depending on the size of the spleen, and place them on ice.

Splenocytes can be frozen at this stage if they are not used for the fusion.

18. Count both SP $2 / 0$ cells and splenocytes using a Countess Cell Counter. For cell counting, mix $10 \mu \mathrm{L}$ of cell suspension $+10 \mu \mathrm{L}$ of Trypan Blue in a tube or a well of a 96-well plate. Add $10 \mu \mathrm{L}$ of this mixture to the counting slide (or a hemocytometer). Insert the slide in the Countess, adjust the magnification after zooming, and then start counting. If a Countess is not available, count the cells using any standard hemocytometer.

19. Combine splenocytes and SP $2 / 0$ in a $50-\mathrm{mL}$ centrifuge tube at a $1: 2$ to $1: 4$ ratio (spleen: myeloma). Gently mix and centrifuge them at $1400 \mathrm{rpm}$ for $7 \mathrm{~min}$ at room temperature.

\section{Spleen-Myeloma Fusion}

20. Carefully aspirate all of the supernatant off the cell pellet. Do not loosen the pellet, and aspirate as much supernatant as possible.

21. Add $1 \mathrm{~mL}$ of PEG 1450 ( $1 \mathrm{~mL}$ for every $\sim 0.5 \times 10^{9}$ cells) to the pellet slowly (drop by drop) over a period of $1 \mathrm{~min}$. Mix the pellet thoroughly while adding PEG.

22. Incubate the cells for $1 \mathrm{~min}$ at room temperature after adding PEG. 
23. Slowly add warm PBS (from the water bath) to the cells at a rate of $1 \mathrm{~mL}$ the first minute, $2 \mathrm{~mL}$ the second minute, $3 \mathrm{~mL}$ the third minute, and so on, up to the seventh minute, with constant stirring. In the last $2 \mathrm{~min}$ (eighth and ninth minutes), slowly add the remaining PBS to the cells.

24. Incubate the postfusion cell suspension for at least $10 \mathrm{~min}$ in the $37^{\circ} \mathrm{C}$ water bath. Centrifuge the cells at $1000 \mathrm{rpm}$ for $7 \mathrm{~min}$ with break-off.

25. Pour off the supernatant, and resuspend the pellet gently in HAT medium at $10 \mathrm{~mL}$ per 96 -well plate.

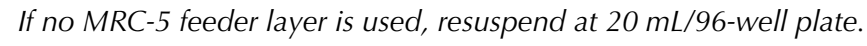

26. Pass the cells through a $70-\mu \mathrm{m}$ cell strainer to remove any debris formed during fusion. Wash the strainer with some HAT medium to avoid any cell loss.

27. Add $100 \mu \mathrm{L}$ of cell suspension/well to the 96 -well plate ( $200 \mu \mathrm{L} /$ well if no feeder layer is used) using a multichannel pipette (preferably 12-channel).

\section{Postfusion Cell Culture}

28. Check the plates the next day for any contamination. Feed the plates $7 \mathrm{~d}$ after fusion. Remove at least $100 \mu \mathrm{L}$ from each well using a multichannel pipette or vacuum manifold, and replace it with fresh HT medium (medium with everything in HAT medium except aminopterin). Gentamicin is not required and cloning factor is optional from this stage.

See Troubleshooting.

29. Hybridoma colonies should start to grow in $\sim 7 \mathrm{~d}$ postfusion. When the medium starts turning yellow or the wells appear to be confluent, it is time to screen. This usually happens after 10-12 d (in some cases, $14 \mathrm{~d}$ ).

See Troubleshooting.

30. Collect $\sim 120 \mu \mathrm{L}$ of supernatant from each well for screening. Add fresh HT medium as in Step 28 again. If screening has to be performed on Day 14, feed the plates one more time on Day 10. Leave the plates without changing medium for at least $3 \mathrm{~d}$ before screening. This facilitates accumulation of antibody in the supernatant.

31. Once positive hybridomas are identified after the fusion screen, expand them to a 24-well plate. Rescreen the hybridomas at the 24-well stage to make sure that they are still positive and are making target-specific antibody.

See Troubleshooting.

32. After the second screen (or once the 24 -well plate is confluent), transfer the hybridomas to a T25 flask. Only target-specific hybridomas need to be expanded. From this stage onward, gradually reduce the serum concentration (cloning factor, NCTC medium, and gentamicin are not required for this step).

33. Once the hybridomas are expanded to a T25 flask, gradually reduce the HT concentration in the medium: that is, start adding D-10 medium $50 \%$ every time so that eventually the cells are completely in D-10 medium. HT weaning should start after four to five passages from the day fusion was performed (first passage on Day 7; second on Day 10; third on Day 12 or 14, which is the 24-well plate after fusion screening; fourth on Day 17 in T25 flask).

34. Freeze at least two vials of parental hybridomas (two vials per T25 flask). Subclone any potential positives as early as possible (i.e., immediately after identifying specific target hybridomas at the 24-well stage). 
Problem (Step 28): Myeloma cells are not dying off after fusion.

Solution: Make up fresh HAT medium at $2 \times$ concentration. Remove half the medium from each well, and add the fresh $2 \times$ HAT medium.

Problem (Step 28): The fusion is contaminated with bacteria.

Solution: Collect peritoneal macrophages from one to three mice of the same strain as the spleen donor. Wash them two times and resuspend in sufficient HAT medium to add $50 \mu \mathrm{L}$ of macrophages to each well in the fusion plate(s). Macrophages should clear the contamination.

Problem (Step 29): No hybridomas are produced.

Solution: Consider the following.

- The immunization protocol may not have produced activated B cells, an unlikely situation if an adjuvant was used. Try a different adjuvant or immunization method to increase the titer.

- Hybridoma formation and growth may be inadequate. This can occur if the cells (spleen or fusion partner) were contaminated with mycoplasma. Obtain the fusion partner from a reliable source, either a laboratory that is successfully producing hybridomas or from ATCC. Freeze aliquots of these cells as soon as possible to maintain a clean stock. Only use animals from specific pathogenfree suppliers, and cage them in uncontaminated rooms.

- The lot of fetal bovine serum (FBS) does not support hybridoma growth. Test the FBS for a lot that supports high-efficiency cloning using stable hybridoma lines or the fusion partner cells (see Protocol: Screening for Good Batches of Fetal Bovine Serum for Myeloma and Hybridoma Growth [Greenfield 2018]).

- Lack of sufficient growth factors. Add growth supplement like hybridoma growth factor or feeder cells.

Problem (Step 31): Viable hybridomas are produced at the anticipated level, but the desired monoclonal antibody is not found.

Solution: Consider the following.

- You may just have been unlucky and none of the reactive B cells present in the spleen survived fusion. Try fusing another animal.

- The timing between the final boost and when to remove the spleen may be a little different for this particular antigen. Try collecting the spleen a day later than you did before.

- It may be useful to consider alternative immunization methods, choice of animals, and screening assays.

Problem (Step 31): The hybridoma stopped making antibody.

Solution: If none of the cloned hybridomas secrete the desired monoclonal antibody, the hybridoma was not producing the monoclonal antibody initially (false positive), the hybridoma producing the monoclonal antibody died off before subcloning, or the clones have lost the ability to produce the monoclonal antibody because of chromosome loss. Check for mycoplasma contamination. If there is still some activity left in the parental culture, re-subcloning or making a transfected cell line by isolating the VH and VL genes can be tried to recover the hybridoma. Make sure that the myeloma partner cells are in log phase when collecting them for the fusion. 
E.A. Greenfield

Problem (Step 31): There is very high titer but no stable hybridomas.

Solution: Too much of a good thing may be a bad thing. The B cells may have been overstimulated. Try fusing a mouse with a titer between 1:20,000 and 1:80,000.

\section{RECIPES}

D-10 Medium for Hybridomas

\begin{tabular}{lllll} 
Reagent & $\begin{array}{c}\text { Volume to } \\
\text { add }(\mathrm{mL})\end{array}$ & Manufacturer & $\begin{array}{c}\text { Catalog } \\
\text { number }\end{array}$ & Strength \\
\hline DMEM & 180 & Cellgro & $15-017-\mathrm{CM}$ & \\
Fetal bovine serum & 75 & HyClone & SH30070.03 & $\sim 25 \%$ \\
Glutamax & 3.9 & GIBCO & 35050 & $100 \times$ \\
Pen/strep & 3.9 & GIBCO & 15140 & $100 \times$ \\
Gentamicin & 0.3 & Sigma-Aldrich & G1397 & \\
Hybridoma Cloning Supplement & 9 & PAA Laboratories & F05-009 & $3 \%$
\end{tabular}

${ }^{\mathrm{a} O p t i o n a l . ~}$

HAT Fusion Medium

\begin{tabular}{|c|c|c|c|c|}
\hline Reagent & $\begin{array}{l}\text { Volume to } \\
\text { add }(\mathrm{mL})\end{array}$ & Manufacturer & $\begin{array}{l}\text { Catalog } \\
\text { number }\end{array}$ & Strength \\
\hline DMEM & 180 & Cellgro & 15-017-CM & \\
\hline Fetal bovine serum & 75 & HyClone & SH30070.03 & $\sim 25 \%$ \\
\hline Glutamax & 3.9 & GIBCO & 35050 & $100 \times$ \\
\hline Pen/strep & 3.9 & GIBCO & 15140 & $100 x$ \\
\hline NCTC-109 & 39 & GIBCO & 21340 & \\
\hline Gentamicin & 0.3 & Sigma-Aldrich & G1397 & \\
\hline HAT supplement ${ }^{\mathrm{a}}$ & 4 & ATCC & $69-X$ & \\
\hline Hybridoma Cloning Supplement & 9 & PAA Laboratories & F05-009 & $3 \%$ \\
\hline
\end{tabular}

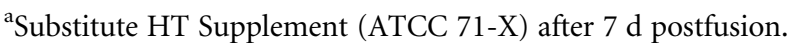

\section{REFERENCES}

Galfre G, Howe SC, Milstein C, Butcher GW, Howard JC. 1977. Antibodies to major histocompatibility antigens produced by hybrid cell lines. Nature 266: 550-552.

Greenfield EA. 2017. Harvesting tissue from immunized mice, rats, and hamsters. Cold Spring Harb Protoc doi: 10.1101/pdb.prot100362.
Greenfield EA. 2018. Screening for good batches of fetal bovine serum for myeloma and hybridoma growth. Cold Spring Harb Protoc doi: 10.1101/ pdb.prot 103150 . 


\section{Polyethylene Glycol Fusion for Hybridoma Production}

Edward A. Greenfield

Cold Spring Harb Protoc; doi: 10.1101/pdb.prot103176

\begin{tabular}{|c|c|}
\hline $\begin{array}{r}\text { Email Alerting } \\
\text { Service }\end{array}$ & Receive free email alerts when new articles cite this article - click here. \\
\hline $\begin{array}{l}\text { Subject } \\
\text { Categories }\end{array}$ & $\begin{array}{l}\text { Browse articles on similar topics from Cold Spring Harbor Protocols. } \\
\text { Antibodies (119 articles) } \\
\text { Antibodies, general (289 articles) } \\
\text { Cell Culture (301 articles) } \\
\text { Generating Antibodies ( } 71 \text { articles) } \\
\text { Generating Antibodies, general (60 articles) } \\
\text { Hybridomas and Myelomas ( } 38 \text { articles) } \\
\text { Immunology, general (128 articles) } \\
\text { Monoclonal Antibodies (32 articles) }\end{array}$ \\
\hline
\end{tabular}

